\title{
XXVIII.-On the invertebrate marine fauna and fishes of St. Andrews
}

\section{W.C. M'Intosh}

To cite this article: W.C. M'Intosh (1874) XXVIII._On the invertebrate marine fauna and fishes of St. Andrews , Annals and Magazine of Natural History, 14:81, 192-207, DOI: $\underline{10.1080 / 00222937408680955}$

To link to this article: http://dx.doi.org/10.1080/00222937408680955

$$
\text { 盂 Published online: } 15 \text { Oct } 2009 .
$$

Submit your article to this journal $\square$

Џ Article views: 6

Q View related articles $\sqsubset$ 
XXVIII.-On the Invertebrate Marine Fauna and Fishes of St. Andrews. By W. C. M'Tintosh.

[Continued from p. 155.]

\section{Subclass ANNULATA DISCOPHORA.}

Fam. 1. Hirudinea, Savigny.

Genus Pontobdelia, Leach.

Pontobdella muricata, L.; Johnst. Cat. p. 39.

Abundant on skate, and tossed on the West Sands after storms.

Pontobdella littoralis, Johnst. Cat. p. 42.

Not uncommon on Cottus bubalis thrown on the West Sands after storms, and occasionally in the stomach of the haddock. It is curious that an example of Piscicola geometra should have been found on the former fish on the sands near the mouth of the Eden.

Fam. 5. Malacobdellea, J. V. Carus.

Genus Malacobdella, Blainville.

Malacobdella grossa, O. F. Müller; Johnst. Cat. p. 35.

Occasionally in Cyprina islandica. The late Dr. Fraser Thomson procured my specimen.

\section{Subclass ANNULATA OLIGOCHAETA.}

Fam. Lumbricina, D'Ud.

Genus Clitellio, Sav.

Clitellio arenarius, O. F. Müller ; Johnst. Cat. p. 66.

In swarms under stones on sandy and muddy ground between tide-marks.

\section{Subclass ANNULATA POLYCHZTA.}

Fam. 3. Aphroditida.

Genus Aphrodita, L.

Aphrodita aculeata, L.; Malmgren, Annulat. Polychæt. \&c. p. 3.

Abundant in deep water, and thrown on the West Sands 
in thousands after some winter storms. It is also a common diet of the cod and haddock.

\section{Fam. 4. Polynoidæ.}

Genus LePIDonotus, Leach.

Lepidonotus squamatus, L.; Mgrn. op. cit.p. 4.

Frequent in deep water, under stones in pools between tidemarks, on the West Sands after storms, and in the stomachs of cod and haddock.

Genus Nrchia, Mgrn.

Nychia cirrosa, Pallas; Mgrn. op. cit. p. 5.

Occasionally in deep water, and on the West Sands after storms.

Genus Lagisca, Mgrn.

Lagisca propinqua, Mgrn. op. cit. p. 9.

Occasionally in débris of the fishing-boats. It is distinguished by its greyish scales mottled with black, by the dark spots at the bases of the feet, the mottling of the dorsum beneath the scales, and by the position of the eyes (the posterior pair only being visible from the dorsum). The dorsal bristles have a short clear portion at the tip; the ventral are long, much tapered and minutely bifid superiorly, while the inferior have shorter and stouter tips, more evidently bifid.

\section{Genus Harmothö̈, Kinberg.}

Harmothö̈ imbricata, L.; Mgrn. op. cit. p. 9.

Very abundant under stones between tide-marks, and ranging to deep water.

Harmothoë lunulata, Delle Chiaje, Descriz. e Not. pl. 144.

f. 5 \& 6 (fide Claparède).

Occasionally on the West Sands after storms.

Harmothö̈ Macleodi, M'Intosh.

Stomach of the cod. It is allied to H. zetlandica in regard to general appearance and processes. Scales fourteen to fifteen pairs, pale and semitranslucent; dorsal cirri scarcely extend beyond the bristles; serrations of the dorsal bristles continued to the tip; ventral bristles boldly bifid, and with rather broad tips. 


\section{Genus Polynö̈, Sav.}

Polynoë floccosa, Savigny, Syst. des Annél. p. 23.

Not uncommon on the West Sands after storms, and under stones between tide-marks.

\section{Genus Evarne, Mgrn.}

Evarne impar, Johnst.; Mgrn. op. cit. p. 10.

Occasionally under stones in pools between tide-marks, and in littoral sponges.

\section{Genus Lenilla, Mgrn.}

Lanilla setosissima, Savigny, Syst. des Annél. p. 25 ;

$$
\text { Mgrn. op. cit. p. } 12 .
$$

Polynö̈longisetis, Grube; Lanilla glabra, Mgrn.; and Harmothö̈ Malmgreni, Lankester.

Tossed on the West Sands after storms, amongst tangleroots. Not uncommon.

\section{Genus Hermadion, Kinberg. \\ Hermadion pellucidum, Ehlers, Die Borstenwürmer, i. p. 105, pls. 3 \& 4.}

Occasionally in deep water amongst corallines and shells.

\section{Hermadion assimile, M'Intosh.}

Amongst the debris in the fishing-boats. This species is easily discriminated from the foregoing (in spirit) by the presence of a brownish-black band commencing behind the head, and continuing along the central line to the tail. Dorsal bristles with the rows of spikes much less marked, and with a notch at the tip of each bristle; the ventral bristles have a somewhat blunt tip, with processes or beaks which differ characteristically from those of the foregoing.

\section{Genus Halosydna, Kinberg.}

Halosydna gelatinosa, Sars; Mgrn. op. cit. p. 14.

Not uncommon under stones in rock-pools and in the stomach of the cod. 
Genus Malmgrenia, M'Intosh.

Malmgrenia andreapolis, M'Intosh.

Amongst the débris in the fishing-boats, in the stomachs of cod and haddock, and abundantly on the West Sands after storms. The scales have a persistent brown belt. Dorsal bristles terminated by a peculiar knob; ventral bifid, but the distal process is constituted by a modification of the knob.

Genus Enipo, Mgrn.

Enipo Kinbergi, Mgrn. op. cit. p. 15.

Occasionally in the stomachs of cod and haddock.

Fam. 6. Sigalionidæ.

Genus Strhenelais, Kinberg.

Sthenelais boa, Johnst. Cat. Brit. Mus. p. 124.

Not uncommon between tide-marks under stones.

Sthenelais limicola, Ehlers, Die Borstenwürmer, i. p. 120, pls. 4 \& 5 .

Abundant on the West Sands after storms, and in the stomachs of cod, haddock, and flounders.

Genus Sigalion, M.-Edwards.

Sigalion Mathildoe, M.-Ed. Hist. du Litt. de la France, ii. p. 105 , pl. 2.

Common on the West Sands after storms, and in the stomachs of cod and haddock.

Genus Рноцоё, Johnst.

Pholoë minuta, Fab.; Mgrn. op. cit. p. 17.

Frequent under stones between tide-marks, and also in deep water.

Fam. 7. Nephthydidx.

Genus Nephthys, Cuvier.

Nephthys coeca, Fab.; Mgrn. op. cit. p. 18.

Common on the beach after storms, in sand under stones between tide-marks, and in the stomachs of cod, haddock, and other fishes. 
Nephthys Hombergii, Aud. \& Ed. Hist. Litt. olim cit. p. 235, pl. 5 B. f. 1-6.

Not uncommon between tide-marks, and in the stomachs of cod and haddock.

Nephthys Johnstoni (longisetosa, Johnst.).

Occasionally between tide-marks, and in the stomachs of cod and haddock. This quite differs from the $N$. longisetosa of Crrsted, Malmgren, and others.

\section{Fam. 8. Phyllodocidæ.}

Genus Notophyluum, GErst.

Notophyllum foliosum, Sars; Mgrn. op. cit. p. 19.

Amongst the débris of the fishing-boats. Not common.

Genus Genetyllis, Mgrn.

Genetyllis lutea, Mgrn. op. cit. p. 20.

Occasionally in deep water.

\section{Genus Phyldodoce, Savigny.}

Phyllodoce gronlandica, Crst.; Mgrn. op. cit. p. 21.

Thrown in numbers on the West Sands after storms; stomachs of cod and haddock.

Phyllodoce maculata, O. F. Müller; Johnst. Cat. p. 177.

Common under stones between tide-marks.

Phyllodoce laminosa, Savigny; Mgrn. op. cit. p. 24.

Frequent between tide-marks, in the laminarian region, on the West Sands after storms, and in the stomachs of cod, haddock, and other fishes.

\section{Genus Eumida, Mgrn.}

Eumida sanguinea, Erst., and var.; Mgrn. op. cit. p. 25.

Common between tide-marks under stones, and on the West Sands after storms.

Genus Eulalia (Sav.), Mgrn.

Eulalia viridis, O. F. Müller; Mgrn. op. cit. p. 25.

Abundant between tide-marks, and ranging to deep water. 
Eulalia bilineata, Johnst.; Mgrn. op. cit. p. 25.

Under stones in rock-pools. Frequent.

Eulalia tripunctata, n. sp.

Amongst the débris of the fishing-boats. Colour pale yellow, with three rows of black spots on the dorsum.

Genus Eteone (Sav.), Mgrn.

Eteone picta, De Quatref. Annelés, ii. p. 147.

West Sands after storms, in the stomachs of cod and haddock, and rarely under stones at the East Rocks.

Eteone andreapolis, M'Intosh.

On the West Sands after storms. The species has large eyes, a peculiarly shaped head, and madder-brown or purplish bands on the dorsum.

Eteone arctica, Mgrn. (?); Mgrn. op. cit. p. 27.

West Sands after storms.

Genus Eteonelia, M'Intosh.

Eteonella Robertiance, M'Intosh.

Found whilst digging for littoral annelids. It appears to be most closely allied to Eteone longa, Ersted. Head conical, with a distinct furrow on each side; and, like Malmgren's Chotoparia, the cephalic and buccal segments seem to be united; for two short filiform tentacles proceed from the posterior part of the head; the mouth, moreover, opens in the cephalic segment; no visible eyes in spirit; there is a distinct elevation in the centre of the head posteriorly; the lobes of the feet are lanceolate.

Fam. 9. Hesionidæ.

Genus Castalia, Savigny.

Castalia punctata, O. F. Müller; Mgrn. op. cit. p. 31.

Not uncommon in deep water, and occasionally under stones near low-water mark.

Genus Psamathe, Johnst.

Psamathe fusca, Johnst. Cat. Brit. Mus. p. 182, pl. 14 a. f. 4.

Frequent under stones in pools and moist places between tide-marks. 
Fam. 10. Syllidæ.

Genus Autolytus, Grube.

Autolytus prolifer, O. F. Müller; Mgrn. op. cit. p. 32.

Not uncommon near low-water mark under stones, and ranging to deep water.

Autolytus (Procercea) pictus, Ehlers, Die Borstenwürmer, i. p. 256 , pl. 11. f. 8-17.

Occasionally under stones in tide-pools. This form also appears to show alternation of generations.

Genus Eusyluls, Mgrn.

Eusyllis tubifex, Gosse (?); M'Intosh, Trans. Roy. Soc. Edinb. vol. $\mathrm{xxv}, 2$. p. 414.

Abundant on laminarian blades cast ashore by storms.

Genus Exogone, Erst. (Sphcerosyllis).

Exogone naidina, Erst. (?), Archiv f. Naturg. xi. 1845,

$$
\text { p. 20, Taf. } 2 .
$$

Occasionally under stones in rock-pools.

Genus Syllis, Savigny.

Syllis armillaris, O. F. Müller; Mgrn. op. cit. p. 42.

Frequent between tide-marks under stones and in the laminarian region.

\section{Genus "IordA," Johnst.}

"Ioida macrophthalma," Johnst. Cat. Brit. Mus. p. 197, pl. 14 a. f. 5.

Occasionally between tide-marks. This is the sexual bud of a Syllis. Four or five of the segments anteriorly are devoid of the long bristles.

Fam. 11. Nereidx.

Genus Nereis, L.

Nereis pelagica, L.; Mgrn. op. cit. p. 47.

Everywhere abundant from high-water mark to the coralline ground, and in the stomachs of many fishes. 
Nereis cultrifera, Grube; Ehlers, Die Borstenwürmer, ii. p. 461, pls. 18-20.

Frequent between tide-marks under stones on muddy ground, and in the stomachs of various fishes.

Nereis Dumerilii, Aud. \& Ed.; Ehlers, op. cit. p. 535.

It is curious that only the epitocous form (olim Iphinereis fucicola) has yet occurred, viz. in the coralline region and on the West Sands after storms.

Genus Hediste, Mgrn.

Hediste diversicolor, O. F. Müller; Mgrn. op. cit. p. 49.

Occasionally between tide-marks, and after storms on the West Sands.

Genus Eunereis, Mgrm.

Eunereis longissima, Johnst.; Mgrn. op. cit. p. 57.

Occasionally cast ashore on the West Sands after storms. This is an epitocous form, the relations of which are at present in obscurity; there is no known species with which it may be connected except those mentioned here.

Genus Nereilepas, Blainville.

Nereilepas fucata, Savigny; Mgrn. op. cit. p. 53.

Abundant on the coralline ground, chiefly in company with Pagurus in Buccinum. It also occurs in the stomachs of various fishes.

$$
\begin{aligned}
& \text { Genus AlitTA, Kinberg. } \\
& \text { Alitta virens, Sars; Mgrn. op. cit. p. } 56 \text {. }
\end{aligned}
$$

Sometimes thrown in large numbers on the West Sands after storms, and not uncommion in the stomachs of cod.

\section{Fam. 13. Lumbriconereidæ.}

Genus Lumbriconereis (Blainv.), M.-Edwards. Lumbriconereis fragilis, O. F. Müller; Mgrn. op. cit. p. 63.

West Sands after storms, and in the stomachs of haddock and flounders. Not rare.

Lumbriconereis Laurentiana, Grube, Archiv f. Naturg. Bd. xxix. 1863, p. 40.

Stomachs of cod and haddock. 
Fam. 15. Onuphididx.

Genus Onuphis, Sars.

Onuphis tubicola, O. F. Müller; Mgrn. op. cit. p. 67.

Fragmentary specimen in the stomach of a haddock.

Fam. 16. Goniadidæ.

Genus Goniada, Aud. \& M.-Ed.

Goniada maculata, Erst. ; Mgrn. op. cit. p. 68.

Common in the stomachs of cod and haddock.

\section{Fam. 17. Glyceridæ.}

Genus Guycera, Savigny.

Glycera dubia, Blainv. (vel Rowxii, Aud. \& M.-Ed.?).

West Sands after storms and in fissures of rocks.

Glycera capitata, Erst.; Mgrn. op. cit. p. 70.

Occasionally in the stomachs of cod and haddock.

Glycera Goësi, Mgrn. op. cit. p. 71.

Stomachs of cod, haddock, and flounders. Not uncommon.

Fam. 18. Ariciidæ.

Genus Aricla, Savigny.

Aricia Cuvieri, Aud. \& M.-Ed.; Mgrn. op. cit. p. 71.

Common between tide-marks in sand, and thrown on the West Sands after storms.

Genus Scoloplos (Blainv.), CErst.

Scoloplos armiger, O. F. Müller; Mgrn. op. cit. p. 72.

Frequent between tide-marks under stones on sandy ground.

\section{Fam. 19. Opheliidæ.}

Genus Ammotrypane, H. Rathke.

Ammotrypane aulogaster, H. Rathke; Mgrn. op. cit. p. 73.

Occasionally in the stomachs of haddocks. 
Genus Ophelia (Sav.), M.-Edwards.

Ophelia limacina, H. Rathke; Mgrn. op. cit. p. 74.

Very abundant on the West Sands after storms, and often in the stomachs of cod and haddock.

Genus Travisia, Johnst.

Travisia Forbesii, Johnst.; Mgrn. op. cit. p. 75.

Occasionally under stones on gravel at East Rocks, and in the stomachs of flounders.

Fam. 20. Scalibregmidæ.

Genus Eumenia, Girst.

Eumenia crassa, CErst.; Mgrn. op. cit. p. 76.

In the stomach of the haddock. Not uncommon.

Genus Scalibregma, H. Rathke.

Scalibregma inflata, H. Rathke; Mgrn. op. cit. p. 77.

In the stomach of a flounder. Rare.

Fam. 21. Telethusidx.

Genus Arenicola, Lamarck.

Arenicola marina, L.; Mgm. op. cit. p. 78.

Everywhere abundant in sandy ground.

Fam. 22. Sphærodoridæ.

Genus Ephesia, H. Rathke.

Ephesia gracilis, H. Rathke; Mgrn. op. cit. p. 79.

Occasionally between tide-marks, and frequently in the coralline region.

Fam. 23. Chloræmidæ.

Genus Trophonia, M.-Edwards.

Trophonia plumosa, O. F. Müller; Mgrn. op. cit. p. 82.

Common on the beach after storms, in muddy fissures of the rocks between tide-marks, and ranging to deep water, as well as in the stomachs of various fishes.

Ann. \& Mag. N. Hist. Ser. 4. Vol. xiv. 
Genus Flabelligera, Sars.

Flabelligera affinis, Sars; Mgrn. op. cit. p. 83.

Frequent in deep water, and sometimes between tide-marks.

Fam. 25. Chætopteridæ.

Genus Chatopterus, Cuvier.

Chatopterus norvegicus, Sars; Mgrn. op. cit. p. 88.

Occasionally in the stomachs of haddock.

Genus MæA, Johnst.

Moea mirabilis, Johnst. Cat. Brit. Mus. p. 278.

Not uncommon amongst gravelly sand off the East Rocks. The position of this remarkable form may be regarded as provisional (between the Chætopteridæ and Spionidæ).

Fam. 26. Spionidæ.

Genus Nerine, Johnst.

Nerine foliosa, Sars; Mgm. op. cit. p. 89.

Common in sandy ground or in maddy sand.

Genus Scolecolepis, Blainv.

Scolecolepis vulgaris, Johnst.; Mgrn. op. cit. p. 90.

Not uncommon in muddy sand.

Genus SpIo, Erst.

Spio seticornis, Fab.; Mgrn. op. cit. p. 92.

In fine sand tubes under stones at the East Rocks.

Genus Polydora, Bosc.

Polydora ciliata, Johnst.; Mgrn. op. cit. p. 95.

Very abundant in soft sandstone and shale. 
Fam. 27. Cirratulidæ.

Genus Crrratulus, Lamarck.

Cirratulus cirratus, O. F. Müller; Mgrn. op cit. p. 95.

Common in mud and muddy sand under stones between tide-marks, and ranging to deep water.

\section{Genus Dodecaceria, Erst.}

Dodecaceria concharum, Erst.; Mgrn. op. cit. p. 96.

Not unfrequent in tangle-roots and old shells from lowwater mark to the coralline ground.

Fam. 28. Capitellidø.

Genus Capitella, Blainville.

Capitella capitata, Fab.; Mgrn. op. cit. p. 97.

Common on the West Sands after storms and in fissures of rocks in mud.

Fam. 29. Maldanidæ.

Genus Maldane, Grube.

Maldane biceps, Sars; Mgrn. op. cit. p. 98.

A fragmentary specimen in the stomach of a haddock.

Genus Nichomache, Mgrn.

Nichomache lumbricalis, Fabr.; Mgrn. op. cit. p. 99.

Common between tide-marks under stones, and thence to deep water ; it is especially abundant in vertical fissures of the soft sandstone at the East Rocks.

Genus Praxilla, Mgrn.

Praxilla protermissa, Mgrn. op. cit. p. 100.

In the stomach of a haddock. Not common.

Fam. 30. Ammocharidæ.

Genus Owenia, Delle Chiaje.

Owenia fliformis, Delle Chiaje; Claparede, Chæt. Naples, p. 446, pl. 26. f. 5 .

Common in the stomachs of haddock. 
Fam. 31. Hermellidæ.

Genus Sabeldaria, Lamarck.

Sabellaria spinulosa, R. Leuckart; Mgrn. op. cit. p. 102.

Abundant between tide-marks, and thence to deep water.

Fam. 32. Amphictenidæ.

Genus Pectinaria, Lamarck.

Pectinaria belgica, Pallas; Mgrn. op.cit. p. 103.

Very abundant off the West Sands, and tossed ashore in vast numbers after storms. Common in the stomachs of cod and haddock.

Genus Ampuictene, Sav.

Amphictene auricoma, O. F. Müller; Mgrn. op. cit. p. 103.

Occasionally off the East Rocks in sandy ground, and in the stomachs of cod, haddock, and flounders.

Fam. 33. Ampharetidæ.

Genus Ampharete, Mgrn.

Ampharete arctica, Mgrn. op. cit. p. 104.

Occasionally in deep water and in the stomachs of haddock.

Genus Amphicteis (Gr.), Mgrn.

Amphicteis Gunneri, Sars; Mgrn. op. cit. p. 105.

Not uncommon in the stomachs of haddock.

Genus Melinna, Mgrn.

Melinna cristata, Sars; Mgrn. op. cit. p. 106.

Frequent in the stomachs of cod.

Fam. 34. Terebellidæ.

Subfam. 1. Amphitrited, Mgrn.

Genus AMPhitrite, O. F. Müller.

Amphitrite figulus, Dalyell; Mgrn. op. cit. p. 107 (as $A$. Johnstoni).

Not uncommon between tide-marks, and ranging to deep water. 
Genus Lanice, Mgrn.

Lanice conchilega, Pallas; Mgrn. op. cit. p. 108.

Abundant between tide-marks and off the West Sands, and multitudes are thrown on the beach after storms. A common food of many fishes.

Genus Nicolea, Mgrn.

Nicolea zostericola, CErst. \& Gr.; Mgrn. op. cit. p. 109.

Common between tide-marks amongst tangle-roots, and ranging to deep water.

Genus Thelepus, Leuckart.

Thelepus circinatus, Fab.; Mgrn. op. cit. p. 110.

Frequent in the laminarian and coralline regions, in the stomachs of various fishes, and on the West Sands after storms.

Subfam. 2. Polyctratdra, Mgrn.

Genus Polycirrus, Grube.

Polycirrus (Ereutho) Smitti, Mgrn. op. cit. p. 111.

Not uncommon between tide-marks.

Subfam. 5. CANEPHoRIDEA, Mgrn.

Genus Terebellides, Sars.

Terebellides Strcemii, Sars; Mgrn. op. cit. p. 112.

Large specimens occur in the stomachs of cod and haddock.

\section{Fam. 35. Sabellidæ.}

Genus Sabelia, L.

Sabella pavonia, Sav.; Mgrn. op. cit. p. 112.

Abundant in the coralline ground, on the West Sands after storms, and in the stomach of the cod.

Sabella (Branchiomma, Kölliker) vesiculosa, Mont.; Johnst. Cat. Brit. Mus. p. 259.

Frequently thrown on the West Sands after storms. 
Sabella viridis, M.-Edwards, Règ. An. Illust. pl. $1 e$ (fide De Quatref.).

Amongst mud in the insterstices of Fitigrana implexa from the coralline region.

Genus Dasychone, Sars.

Dasychone Dalyelli, Kölliker; Mgrn. op. cit. p. 115.

Occasionally from the coralline ground in the débris of fishing-boats.

Genus Amphicora, Ehrenberg.

Amphicora Fabricia, O. F. Müller; Mgrn. op. cit. p. 117.

Abundant under stones on muddy ground between tidemarks and amongst tangle-roots.

\section{Fam. 36. Serpulidæ.}

Genus Protula, Risso.

Protula tubularia, Mont. (=protensa, Johnst.) ; Johnst. Cat. Brit. Mus. p. 264.

Occasionally in deep water.

Genus Filigrana, Oken.

Filigrana implexa, Berkeley; Mgrn. op. cit. p. 119.

Fine masses are common in the coralline region.

Genus HydroIdes, Gunner.

Hydroides norvegica, Gunner; Mgm. op. cit. p. 120. Abundant in deep water, attached to shells, stones, \&c.

Genus Serpula, L.

Serpula vermicularis, L.; Mgrn. op. cit. p. 120. Common in deep water.

Genus Pomatocerus, Phil.

Pomatocerus triqueter, L.; Mgrn. op. cit. p. 121. Very common from the littoral to the coralline region. 
Genus SpIrorbis, Daud.

Spirorbis borealis, Daud.; Mgrn. op. cit.p. 122.

Abundant on seaweeds and stones between tide-marks.

Spirorbis lucidus, Mont.; Mgrn. op. cit. p. 123.

Common on zoophytes from deep water.

[To be continued.]

XXIX.-Descriptions and Figures of Deep-sea Sponges and their Spicules from the Atlantic Ocean, dredged up on board H.M.S. 'Porcupine,' chiefly in 1869; with Figures and Descriptions of some remarkable Spicules from the Agulhas shoal and Colon, Panama. By H. J. Carter, F.R.S. \&c.

[Plates XIII., XIV., \& XV.]

I now propose to describe and illustrate for publication a few more of the deep-sea sponges dredged up on board H.M.S. 'Porcupine,' from the bed of the Atlantic Ocean, off the coast of Ireland, or between the north of Scotland and the Faroe Islands-every fragment of which that came into my hands was immediately sketched and preliminarily recorded in my MS. journal, with all the information as regards "soundings \&c." that accompanied them, in order that I might possess the means of referring to any particular specimen directly, and, in case of accident, thus endeavour to provide against total loss,

The greater part of these specimens represent sponges which have already been described; and the rest will be considerably reduced by those which I am now about to add. Among the latter, however, will be found such extraordinary forms of the flesh-spicule that, unless I first describe a well-known one for reference, they will probably not be understood.

As regards nomenclature, it is not desirable to give new names if we wish to speed knowledge; and hence it is better, if possible, to retain an old one, although inappropriate, rather than oppress the mind at the outset by introducing that to which it is unaccustomed. Much that is valuable is never read because it is accompanied by new names.

Again, if we can find familiar types in our British sponges for reference, when engaged in the study of foreign species, it is better to adopt these than to refer to specimens which are less accessible. 